Meijer, J., 1980. Constructie van een ideaalcurve met gebruikmaking van de lognormale verdeling. M.Sc. thesis, Wageningen. $13 \mathrm{pp}$.

Prodan, M., 1949. Die theoretische Bestimmung des Gleichgewichtszustandes im Plenterwalde Schweizerische Zeitschrift für das Forstwesen 100: 81-98.

Roches, D., 1970 Etude comparative des prix de revient d'une récolte en forêt regulière et en forêst jardinée. Schweizerische Zeitschrift für das Forstwesen 121: 215-227.

Satyamurthi. K. R., 1980. Sylvometrics. Indian Forest Record (new series) 2(2).

Usher, M. B., 1969. A matrix model for forest management. Biometrics 25: 309-315.

This synopsis is based on an M. Sc. thesis entitled 'Theorie t.a.v. kap bij kleinschalig bosbeheer', Department of Forest Management, Agricultural University, Wageningen, 1983.44 pp., 5 figs., 4 tables, 30 refs., appendix. Dutch.

Available as paper copy (order R018P, $f 20$ including postage) or microfiche (order R018M, f 12.50 including postage) at: NARD, clo Pudoc, P.O. Box 4, 6700 AA Wageningen, Netherlands (telex 45015 blhwg nl).

\title{
Effect of muscle temperature soon after slaughter on pork quality: a pilot study
}

P. G. van der Wal and G. Eikelenboom (Research Insitute for Animal Production 'Schoonoord', P.O. Box 501, 3700 AM Zeist, Netherlands)

Received 9 July 1984; accepted 3 August 1984

Abstract. The effect of various environmental temperatures, ranging between 42.5 and $25^{\circ} \mathrm{C}$ during the first $2 \mathrm{~h}$ after slaughter, on pork quality was studied in longissimus dorsi samples. Higher environmental temperatures resulted in higher lactate and lower $\mathrm{pH} 2 \mathrm{~h}$ after slaughter. Samples kept at higher environmental temperatures $\left(42.5\right.$ and $40^{\circ} \mathrm{C}$ ) showed characteristics typical for pale soft exudative pork.

Key-words: body temperature, environmental temperature, pork, pale soft exudative, drip loss, meat quality.

Introduction. Pale soft exudative pork is the result of rapid decline in $\mathrm{pH}$ after slaughter and elevated muscle temperature, which cause denaturation of muscular proteins. Heat production in porcine muscle is increased by stress, particularly in stress-susceptible pigs (Sybesma \& Eikelenboom, 1978). With present slaughter procedures, carcase temperature frequently remains high for the first hours after 
slaughter and perhaps exacerbates exudative defects (Sybesma, 1963). The present study was designed to determine the effect of temperature after slaughter on pork quality.

Material and methods. From 8 slaughtered crossbred pigs, part of the longissimus dorsi (between 7 th and 13th ribs) was removed from the right half-carcase immediately after bleeding. Each sample was divided into 6 chops. After being wrapped in polyethylene bags, the respective chops were stored for $2 \mathrm{~h}$ in water baths at temperatures of $42.5,40,37,35,30$ and $25^{\circ} \mathrm{C}$. Control samples from the left half-carcase were left in situ for the same time, during which the carcases underwent normal abattoir procedures. The $\mathrm{pH}$ of experimental and control samples was measured $2 \mathrm{~h}$ after slaughter. Subsamples from all samples were analysed for lactate (Boehringer, Mannheim, test kit TC 124842). After the first two hours, all samples were stored for $2 \mathrm{~h}$ at $25^{\circ} \mathrm{C}$ and $1 \mathrm{~h}$ at $15^{\circ} \mathrm{C}$. They were subsequently all kept at $4{ }^{\circ} \mathrm{C}$. Drip losses were estimated $24 \mathrm{~h}$ after slaughter and pork quality was examined visually (van der Wal et al., 1983) and colour was evaluated (Hunter tristimulus; $\mathrm{L}, \mathrm{a}, \mathrm{b}$; angle $2^{\circ}$; illumination $\mathrm{C}$ ). After being subsampled and extracted for estimation of transmittance at wavelength $600 \mathrm{~nm}$ (a measure of protein solubility; Hart, 1962), alle samples were prepared for the assessment of drip loss during the period 24 to $72 \mathrm{~h}$ after slaughter. Heating loss was then measured for samples kept at $75^{\circ} \mathrm{C}$ for $50 \mathrm{~min}$.

Results. The $\mathrm{pH}$ of samples kept at higher environmental temperatures for two hours after slaughter were significantly lower. The $\mathrm{pH}$ ranged from 6.20 at $25^{\circ} \mathrm{C}$ to 5.49 at $42.5^{\circ} \mathrm{C}$. The samples kept at the highest temperatures also contained significantly more lactate (content in fresh matter 88.1 and $82.6 \mu \mathrm{mol} / \mathrm{g}$ at 42.5 and $40^{\circ} \mathrm{C}$, respectively) than after storage at lower temperatures and than in control samples (about 35 to $40 \mu \mathrm{mol} / \mathrm{g}$ ). The content of lactate in the samples kept at $30(52.0$ $\mu \mathrm{mol} / \mathrm{g})$ and $25^{\circ} \mathrm{C}(41.0 \mu \mathrm{mol} / \mathrm{g})$ was not significantly different from that in corresponding control samples. From visual examination, samples kept at 42.5 and $40{ }^{\circ} \mathrm{C}$ showed pale soft exudative defects. Colour values indicated the same, values on the $\mathrm{L}$ and $\mathrm{b}$ scale being higher in these samples. Similarly protein solubility (higher transmittance of extracts) rapidly decreased at higher temperatures. Drip losses till $72 \mathrm{~h}$ after slaughter increased with initial temperature from 4.7 to $14.2 \%$. In general, heating losses (about 28 to $30 \%$ ) were not significantly different between temperature treatments nor between experimental and control samples.

Discussion and conclusions. High carcase temperature contributes to pale soft exudative defects of pork (Sybesma, 1963). High temperature after slaughter is sometimes attributable to the pig's condition before slaughter, for instance to malignant hyperthermia in stress-susceptible pigs (Sybesma \& Eikelenboom, 1978). Temperatures inside the muscles of many carcases are above $40{ }^{\circ} \mathrm{C}$, even 42 to $43{ }^{\circ} \mathrm{C}$, an hour after slaughter.

Higher temperatures during the first $2 \mathrm{~h}$ after slaughter also increased glycolysis, as indicated by the rapid fall in $\mathrm{pH}$ and the rise in lactate. Both objective evaluation 
(Hunter tristimulus and transmittance), and subjective evaluation of pork quality $24 \mathrm{~h}$ after slaughter indicated pale soft exudative defects (pale colour, high exudation, loose texture, high transmittance of extracts) in the samples kept at higher temperatures $\left(42.5\right.$ and $\left.40^{\circ} \mathrm{C}\right)$. Drip losses $72 \mathrm{~h}$ after slaughter supported these findings.

Higher temperatures soon after slaughter thus stimulate denaturation of sarcoplasmic proteins, so increasing drip losses and pale soft exudative deterioration of pork.

\section{References}

Hart. P.C.. 1962. Fysisch-chemische kenmerken van gedegenereerd vlees bij varkens. 2. Tijdschrift Diergeneeskunde 87: 156-167.

Sybesma, W., 1963. Enterse ziekte onder de huidige omstandigheden: praktische mogelijkheden ter beperking van de schade. Tijdschrift Diergeneeskunde 88: 1043-1049.

Sybesma, W. \& G. Eikelenboom, 1978. Methods of predicting pale, soft, exudative pork and their application in breeding programmes - a review. Meat Science 2: 79-90.

Wal. P. G. van der. G. Eikelenboom \& E. Lambooy, 1983. The effect of electrical stunning on pork quality. In: G. Eikelenboom (Ed.), Stunning of animals for slaughter. Martinus Nijhoff, The Hague, p. $82-89$.

This synopsis is based on a report entitled 'Een modelstudie naar de invloed van de vroeg post mortale spiertemperatuur op de vleeskwaliteit van de m. longissimus dorsi van varkens', Report B-239, Research Institute for Animal Husbandry 'Schoonoord', Zeist, Netherlands, 1984.30 pp., 8 tables, 15 refs. Dutch, English summary and table captions.

Available as paper copy (order R019P, free available) or microfiche (order R019M, f 12.50 including postage) at: NARD, clo Pudoc, P.O. Box 4, 6700 AA Wageningen, Netherlands (telex 45015 blhwg $\mathrm{nl}$ ).

\section{Simulation of the production pattern of rape-seed on the basis of a field experiment}

M. Backx, J. van Duivenvoorden and J. Goudriaan (Department of Theoretical Production Ecology, Agricultural University, P.O. Box 430, 6700 AK Wageningen, Netherlands)

Accepted: 20 August 1984

Abstract. A simulation model for growth and development of rape-seed on the ba- 